\title{
Implementasi Evaluasi Hasil Belajar Pada Sekolah Dengan Program Double Track di Provinsi Jawa Timur
}

\author{
Andika Trirangga Putra ${ }^{1}$, Amalia Dwi Cahyani' ${ }^{2}$, Ayang Elsi Fatmawaty ${ }^{3}$, Muhammad Adip Fanani ${ }^{4}$ \\ andikatrirangga@student.ub.ac.id ${ }^{1}$, maliadwi78@student.ub.ac.id², ayangelsi_23@student.ub.ac.id ${ }^{3}$, \\ adipfanani35@student.ub.ac.id ${ }^{4}$
}

Universitas Brawijaya, Malang, Jawa Timur, Indonesia

\begin{abstract}
Keywords: Assessment of learning, Double Track program

This paper examines implementation of study assessments in school with a double track program in East Java Indonesia. The method of study of libraries is the method used for this research to develop both theoretical and practical benefits for evaluating both learning and double-track programs. The findings show that the implementation of a study evaluation of schools with a double-track program working on goals. Students may obtain a certificate through partners in schools, just as schools may work with e-bizz for TIK, Airlangga Broadcasting for video making skills, SMET for mandarin skills, etc. A double track evaluation of results can be an alternative to solving the problem of the labor shortage and the amount of unemployment that results from lack of employment.
\end{abstract}

Kata Kunci: Evaluasi hasil belajar, program Double Track

\section{INTISARI}

Penelitian ini bertujuan untuk menjelaskan implementasi evaluasi hasil belajar pada sekolah dengan program double track di Jawa Timur. Metode telaah pustaka yaitu metode yang digunakan untuk penelitian ini agar mengembangkan aspek teoritis maupun aspek manfaat praktis mengenai evaluasi hasil belajar dan program double track. Hasil penelitian ini menunjukkan implementasi evaluasi hasil belajar pada sekolah dengan program double track berjalan sesuai tujuan. Siswa dapat memperoleh sertifikat melalui mitra-mitra yang bekerjasama dengan sekolah, seperti halnya sekolah dapat bekerja sama dengan E-Bizz untuk bidang TIK, Airlangga Broadcasting untuk keterampilan pembuatan video, SMET untuk keterampilan bahasa mandarin, dll. Evaluasi hasil belajar dengan program double track dapat menjadi alternatif untuk memecahkan masalah kurangnya tenaga kerja yang produktif dan jumlah pengangguran yang diakibatkan oleh kurangnya lapangan pekerjaan. 


\section{Pendahuluan}

Pendidikan menurut UU Sistem Pendidikan Nasional No. 20 tahun 2003 pasal 1 adalah usaha sadar dan terencana untuk mewujudkan suasana belajar dan proses pembelajaran agar peserta didik secara aktif mengembangkan potensi dirinya untuk memiliki kekuatan spiritual keagamaan, pengendalian diri, kepribadian, kecerdasan. Kemudian, dilanjutkan pada pasal 3 UU Sistem Pendidikan Nasional No. 20 tahun 2003 menyebutkan bahwa Pendidikan nasional berfungsi mengembangkan kemampuan dan membentuk watak serta peradaban bangsa yang bermartabat dalam rangka mencerdaskan kehidupan bangsa, bertujuan untuk berkembangnya potensi peserta didik agar menjadi manusia yang beriman dan bertakwa kepada Tuhan Yang Maha Esa, berakhlak mulia, sehat, berilmu, cakap, kreatif, mandiri, dan menjadi warga negara yang demokratis serta bertanggung jawab. Dengan beberapa penjelasan tersebut, maka dapat dilihat bahwa pendidikan tidak hanya berperan dalam memajukan kecerdasan anak bangsa saja, melainkan juga berperan dalam mengembangkan keterampilan atau potensi yang ada pada peserta didik. Pendidikan yang berkualitas diperlukan agar dapat menghasilkan lulusan yang memiliki kecakapan dan berkompeten dalam berbagai bidang. Peningkatan keterampilan ini sangat diperlukan sebagai bekal untuk peserta didik dalam menjalani kehidupan di dunia kerja. Karenanya peningkatan keterampilan perlu dibentuk sejak dini saat masih berada dibangku sekolah. Hal ini juga bisa menjadi solusi atas masalah yang terkait dengan meningkatnya angka pengangguran yang terjadi di Indonesia saat ini.
Pemenuhan Sumber Daya Manusia (SDM) yang berkualitas saat ini sangat dibutuhkan agar dapat mendukung program pembangunan yang ada di Indonesia dengan baik. Seperti yang telah disampaikan sebelumnya, bahwa salah satu masalah yang saat ini sedang terjadi di Indonesia yaitu meningkatnya jumlah angka pengangguran. Berdasarkan struktur ketenagakerjaan menurut Badan Pusat Statistik (BPS), jumlah angka pengangguran yang ada di Indonesia pada tanggal 21 Agustus 2021 ini berjumlah 9,10 juta orang. Jumlah ini tentunya masih terbilang tinggi. Angka tersebut sebenarnya sudah mengalami penurunan sebesar 0,67 juta orang dibandingkan dengan bulan Agustus tahun 2020 yang lalu mencapai angka 9,77 juta orang. Namun penurunan angka tersebut masih terbilang rendah dan perlu terus diupayakan agar penurunan jumlah angka pengangguran semakin meningkat di tahun berikutnya. Salah satu upaya yang dilakukan oleh pemerintah Provinsi Jawa Timur untuk menekan angka pengangguran ini adalah dengan dibuatnya kebijakan program double track. Dalam hal ini, penulis mengambil studi kasus di Provinsi Jawa Timur. Kebijakan program double track ini salah satunya bisa dilihat pada Peraturan Gubernur Jawa Timur Nomor 139 Tahun 2018 tentang Program Double Track Pada Sekolah Menengah Atas di Jawa Timur. Peraturan tersebut dibuat sehubungan dengan masih banyaknya lulusan Sekolah Menengah Atas (SMA) yang tidak melanjutkan ke perguruan tinggi dan juga untuk meningkatkan indeks pembangunan manusia. Menurut peraturan Gubernur tersebut pada pasal 1 ayat (6) berbunyi Double Track adalah istilah yang diberikan kepada sekolah yang menyelenggarakan 
dua program pendidikan, yaitu pendidikan formal dan program keterampilan kewirausahaan. Pada beberapa SMA yang ada di Provinsi Jawa Timur saat ini telah melaksanakan program double track ini dengan tujuan untuk memberikan bekal keterampilan dalam memasuki dunia kerja bagi para lulusan yang tidak melanjutkan ke jenjang pendidikan tinggi. Selanjutnya pada pasal 3 disebutkan mengenai ruang lingkup penyelenggaraan program double track yang meliputi: (a) pemetaan peserta didik dan pemetaan sekolah; (b) materi pelatihan dan pengembangan program; (c) pendidik, tenaga pelatih (instruktur), sarana dan prasarana; (d) sertifikasi; dan (e) pembiayaan. Dengan adanya kebijakan ini maka diharapkan sekolah-sekolah dapat menerapkan program double track ini sehingga pendidikan yang berlangsung di sekolah dapat menghasilkan lulusan yang tidak hanya memiliki kecerdasan intelektual saja melainkan juga keterampilan yang berkualitas untuk menunjang kebutuhan dalam dunia kerja bagi para lulusan yang tidak melanjutkan ke jenjang pendidikan tinggi. Program double track ini juga diharapkan dapat menjadi solusi atas masalah tingginya angka pengangguran yang ada di Indonesia.

Berdasarkan hal tersebut, maka penulis tertarik untuk meneliti lebih lanjut mengenai halhal yang terkait dengan "Implementasi Evaluasi Hasil Belajar pada Sekolah dengan Program Double Track di Provinsi Jawa Timur". Penulis melakukan penelitian pada kajian ini dengan menggunakan metode telaah pustaka. Menurut Sukardi (2013:33) telaah pustaka merupakan kegiatan yang dilakukan dalam penelitian yang bertujuan untuk mengembangkan aspek teoritis maupun aspek manfaat praktis. Pada kajian ini peneliti menggunakan beberapa literatur yang tersedia, termasuk juga artikel ataupun jurnal ilmiah yang telah terpublikasi. Beberapa hal yang akan diteliti lebih lanjut oleh penulis yaitu mengenai: (1) Implementasi evaluasi hasil belajar; (2) Pengertian program Double Track; (3) Ruang lingkup pelaksanaan program Double Track; dan (4) Implementasi Evaluasi Hasil Belajar Pada Sekolah Dengan Program Double Track di Provinsi Jawa Timur.

\section{Pembahasan}

\section{Implementasi Evaluasi Hasil Belajar}

\section{1) Pengertian Implementasi}

Implementasi merupakan kegiatan atau tindakan yang dilakukan setelah perencanaan matang dan terperinci. Menurut Nurdin (2002) implementasi berkaitan dengan aktivitas, aksi atau tindakan atau sebuah mekanisme suatu sistem, implementasi bukan hanya sebagai aktivitas melainkan kegiatan yang sudah terencana untuk mencapai suatu tujuan.

Menurut Purwanto dan Sulistyastuti (1991), Implementasi intinya merupakan kegiatan yang bertujuan untuk mendistribusikan keluaran kebijakan (to deliver policy output) yang dilakukan oleh para implementor kepada kelompok sasaran (target group) sebagai upaya untuk mewujudkan suatu kebijakan 
Implementasi akan benar-benar dilakukan biasanya ketika perencanaan sudah dianggap fix, implementasi sendiri berasal dari bahasa inggris yaitu "implementation" yang memiliki arti melaksanakan (Mulyasa, 2013). Selanjutnya Guntur (2004) juga berpendapat, bahwa implementasi merupakan perluasan aktivitas yang saling menyesuaikan proses interaksi antara tujuan dan tindakan untuk mencapainya serta memerlukan jaringan pelaksana birokrasi yang efektif.

Sehingga bisa disimpulkan dari pendapat ahli diatas bahawa implementasi merupakan kegiatan yang dilakukan setelah perencanaan yang dibuat sudah benar-benar matang atau fix. Implementasi merupakan aktivitas yang dilakukan secara sistematis untuk mencapai tujuan yang telah direncanakan.

\section{2) Evaluasi Hasil Belajar}

$$
\text { Menurut Zainal Arifin }
$$
mengungkapkan evaluasi adalah komponen krusial dan suatu tahap yang harus ditempuh oleh para tenaga pendidik untuk mengetahui keefektifan suatu pembelajaran.

Menurut Ralph Tyler evaluasi adalah sebuah proses pengumpulan data untuk menemukan seberapa jauh, berkaitan dengan apa, dan bagian tujuan pendidikan mana yang sudah tercapai (Suharsimi, 2009:3). Selain itu menurut Cornabach dan Stufflebeam dalam Suharsimi (2009:3) proses evaluasi tidak hanya mengukur sejauh mana tujuan tercapai, melainkan digunakan sebagai alat membuat keputusan. Menurut Dwi Sapitri Iriani dan Soeharto (2015), “dalam arti luas evaluasi adalah suatu proses dalam merencanakan, memperoleh, dan menyediakan informasi yang sangat diperlukan untuk membuat alternatif-alternatif keputusan”.

Didalam undang-undang No. 20 Tahun 2003 tentang sistem pendidikan Nasional pasal 57 ayat 1 telah dipaparkan bahwa pelaksanaan evaluasi dilakukan dalam rangka pengendalian mutu pendidikan secara nasional sebagai bentuk akuntabilitas penyelenggaraan pendidikan terhadap pihakpihak yang berkepentingan. Selanjutnya pada ayat 2 dijelaskan pula bahwa evaluasi dilakukan kepada peserta didik, lembaga, dan program pendidikan pada jalur formal dan non formal untuk semua jenjang, satuan, dan jenis pendidikan. sedangkan pada Pasal lain yaitu pasal 58 ayat 1 juga dipaparkan bahwa evaluasi dilakukan dengan tujuan untuk memantau proses, kemajuan dan perbaikan hasil peserta didik secara berkelanjutan. Selanjutnya pada pasal 2 dijelaskan evaluasi peserta didik, satuan pendidikan, dan program pendidikan dilaksanakan oleh lembaga mandiri yang dilakukan secara berkala, komprehensif, transparan, dan sistematik sebagai upaya untuk menilai pencapaian Standar Nasional Pendidikan.

Dari para pendapat ahli diatas dapat ditarik suatu kesimpulan bahwa, evaluasi hasil belajar adalah kegiatan untuk mengukur dan menilai kegiatan pembelajaran dari awal hingga akhir keberhasilan kegiatan pembelajaran. Selanjutnya apabila disimpulkan secara komprehensif antara 
implementasi dengan evaluasi hasil belajar adalah kegiatan yang dilakukan untuk menilai suatu proses yang terencana, berkelanjutan dan menyeluruh dalam rangka pengendalian, penjaminan dan penetapan kualitas pembelajaran terhadap berbagai komponen dalam pembelajaran, berdasarkan pertimbangan dan kriteria tertentu, sebagai bentuk pertanggungjawaban guru dalam melaksanakan pembelajaran.

Tujuan evaluasi hasil belajar menurut Zainal Arifin (2013:15) adalah untuk: 1) Mengetahui tingkat penguasaan peserta didik terhadap materi yang telah diberikan. 2) Mengetahui kecakapan, motivasi, bakat, minat dan sikap peserta didik terhadap program pembelajaran. 3) Mengetahui tingkat kemajuan dan kesesuaian hasil belajar peserta didik dengan standar kompetensi dan kompetensi dasar yang telah ditetapkan. 4) Mendiagnosis keunggulan dan kelemahan peserta didik dalam mengikuti kegiatan pembelajaran. 5) Seleksi, yaitu memilih dan menentukan peserta didik yang sesuai dengan jenis pendidikan tertentu. 6) Menentukan kenaikan kelas. 7) Menempatkan peserta didik sesuai dengan potensi yang dimilikinya.

Menurut Zainal Arifin (2013:20), fungsi evaluasi hasil belajar adalah sebagai berikut: 1) Fungsi formatif, yaitu untuk memberikan umpan balik (feedback) kepada guru sebagai dasar untuk memperbaiki proses pembelajaran dan mengadakan program remedial bagi peserta didik. 2) Fungsi sumatif, yaitu menentukan nilai (angka) kemajuan/hasil belajar peserta didik dalam mata pelajaran tertentu, sebagai bahan untuk memberikan laporan kepada berbagai pihak, penentuan kenaikan kelas, dan penentuan lulus tidaknya peserta didik. 3) Fungsi diagnostik, yaitu untuk memahami latar belakang (psikologis, fisik, dan lingkungan) peserta didik yang mengalami kesulitan belajar, yang hasilnya dapat digunakan sebagai dasar dalam memecahkan kesulitankesulitan tersebut. 4) Fungsi penempatan, yaitu menempatkan peserta didik dalam situasi pembelajaran yang tepat (misalnya dalam menentukan program spesialisasi) sesuai dengan tingkat kemampuan peserta didik.

Selanjutnya menurut Anas Sudijono (2012:59-62). Ada enam langkah pokok kegiatan evaluasi hasil belajar, yaitu:

\section{a. Menyusun rencana evaluasi hasil belajar}

Sebelum evaluasi hasil belajar dilaksanakan, harus disusun terlebih dahulu perencanaan secara baik dan matang. Perencanaan evaluasi hasil belajar umumnya mencakup enam jenis kegiatan, yaitu:
a) Merumuskan tujuan dilaksanakannya evaluasi
b) Menetapkan aspek-aspek yang dievaluasi
c) Memilih dan menentukan teknik yang akan dipergunakan dalam pelaksanaan evaluasi


d) Menyusun alat pengukur yang akan digunakan dalam pengukuran hasil belajar

e) Menentukan tolok ukur, norma atau kriteria yang akan dijadikan pegangan atau patokan dalam memberikan interpretasi terhadap data hasil evaluasi

f) Menentukan frekuensi dari kegiatan evaluasi

\section{b. Menghimpun data}

Dalam evaluasi hasil belajar menghimpun data berarti melaksanakan pengukuran misalnya dengan melaksanakan tes hasil belajar ataupun melakukan pengamatan, wawancara atau angket.

\section{c. Melakukan verifikasi data}

Data yang ada disaring terlebih dahulu sebelum melakukan evaluasi. Proses penyaringan ini dikenal dengan istilah penelitian data atau verifikasi data. Verifikasi ini dimaksudkan untuk memisahkan data yang baik (data yang akan dapat memperjelas gambaran yang akan diperoleh mengenai individu atau sekelompok individu yang sedang dievaluasi) dari data yang kurang baik (data yang akan mengaburkan gambaran yang diperoleh apabila data itu ikut diolah).

\section{d. Mengolah dan menganalisis data}

Mengolah dan menganalisis data dimaksudkan untuk memberikan makna terhadap data yang telah berhasil dihimpun dalam kegiatan evaluasi.

\section{e. Memberikan interpretasi dan menarik} kesimpulan

Penafsiran atau interpretasi terhadap data hasil evaluasi pada hakikatnya merupakan verbalisasi makna yang terkandung dalam data yang telah mengalami pengolahan dan penganalisisan. Atas dasar interpretasi terhadap data hasil evaluasi tersebut pada akhirnya dapat dikemukakan kesimpulan-kesimpulan tertentu. Kesimpulan tersebut mengacu pada tujuan dilakukannya evaluasi itu sendiri.

\section{f. Tindak lanjut hasil evaluasi}

Berdasarkan dari hasil analisis dan kemudian disimpulkan maka akan diketahui makna yang terkandung di dalamnya, pada akhirnya evaluator akan dapat mengambil keputusan atau merumuskan kebijakan-kebijakan yang dipandang perlu sebagai tindak lanjut dari kegiatan evaluasi tersebut.

\section{Program Double Track}

Double track merupakan istilah yang diberikan kepada lembaga sekolah yang dalam pelaksanaan kegiatan belajar mengajar menyediakan dua program pendidikan sekaligus yaitu program pendidikan formal seperti sekolah pada umumnya dan program keterampilan kewirausahaan.

Program double track ini merupakan program yang ditetapkan oleh pemerintah provinsi 
Jawa Timur melalui Peraturan Gubernur Jawa Timur Nomor 139 Tahun 2018. Pada peraturan tersebut dijelaskan bahwa latar belakang munculnya program ini adalah masih banyaknya peserta didik setelah lulus sekolah menengah atas yang tidak melanjutkan ke perguruan tinggi, para lulusan SMA yang tidak melanjutkan ke perguruan tinggi diberikan pembekalan keterampilan untuk mempersiapkan diri memasuki dunia pekerjaan, dan juga dalam rangka untuk meningkatkan Indeks Pembangunan Manusia (IPM) sehingga pemerintah Provinsi Jawa Timur perlu menyelenggarakan program double track ini pada Sekolah Menengah Atas (SMA).

Adapun ruang lingkup dalam penyelenggaraan program double track berdasarkan Peraturan Gubernur (Pergub) Jawa Timur Nomor 139 Tahun 2018 pasal 2 (dua) meliputi: (a) pemetaan peserta didik dan pemetaan sekolah; (b). materi pelatihan dan pengembangan program; (c). pendidik, tenaga pelatih (instruktur), sarana dan prasarana; (d). sertifikasi; dan (e). pembiayaan. Ruang lingkup tersebut dijelaskan lebih rinci sebagaimana berikut:

\section{1) Pemetaan Peserta Didik dan Pemetaan Sekolah}

Pemetaan peserta didik merupakan kegiatan yang dilakukan untuk melakukan penjaringan data peminatan peserta didik yang dapat mengikuti program double track ini. Adapun cara pemetaan peserta didik ini berdasarkan Pergub Jawa Timur Nomor 139 (2018) yaitu dengan melakukan pendataan peserta didik pada seluruh SMA yang ada di Jawa Timur dan berpotensi tidak melanjutkan untuk berkuliah di perguruan tinggi. Sehingga bisa disimpulkan tidak seluruh peserta didik tingkat SMA di Jawa Timur bisa mengikuti program ini, hal itu karena sesuai dengan tujuan dari program double track yaitu untuk mempersiapkan peserta didik masuk dalam dunia pekerjaan namun bagi yang tidak melanjutkan ke perguruan tinggi saja. Program ini juga sebagai upaya memberikan keadilan terhadap peserta didik yang tidak melanjutkan kuliah agar tidak kalah saing dengan peserta didik yang melanjutkan kuliah apabila nanti mencari pekerjaan karena sudah dibekali keterampilan pada program double track ini.

Selanjutnya pemetaan sekolah merupakan kegiatan untuk menentukan sekolah mana yang akan diberi tugas untuk menyelenggarakan program double track ini, adapun sekolah SMA yang diberi tugas untuk menyelenggarakan program double track ini adalah SMA yang berlokasi berdekatan dengan SMK (Sekolah Menengah Kejuruan) dimana jumlah peserta didik dari SMA tersebut sebanyak $50 \%$ (lima puluh persen) atau lebih memungkinkan atau berpotensi tidak akan melanjutkan ke perguruan tinggi ketika setelah lulus SMA nanti.

\section{2) Materi Pelatihan dan Pengembangan Program}

Materi pelatihan dari program double track ini wajib disusun oleh lembaga sekolah atau SMA yang terpilih untuk menyelenggarakan program double track dengan mengacu atau sesuai dengan Standar Kompetensi Kerja Nasional Indonesia yang dipilih. Waktu 
pelatihan program ini dilaksanakan pada jam di luar jam sekolah, sedangkan jumlah jam pelatihan disesuaikan dengan ketentuan yang tertuang di dalam Standar Kompetensi Kerja Nasional Indonesia.

Adapun untuk kegiatan pengembangan pada program double track ini yaitu memfasilitasi para lulusan sesuai dengan kompetensi yang dimiliki dengan cara bekerja sama berbagai instansi, dunia usaha dan dunia industri (Pergub Jatim No. 139, 2018).

\section{3) Pendidik, Tenaga Pelatih (Instruktur),}

\section{Sarana Dan Prasarana}

Pendidik yang dimaksud pada program double track merupakan pendidikan yang memiliki sertifikat keahlian yang diperoleh dari Badan Nasional Sertifikasi Profesi. Sedangkan, yang dimaksud tenaga pelatih (instruktur) merupakan tenaga pelatih yang mampu memberikan materi pelatihan yang sesuai dengan kompetensi yang dimiliki. Sehingga apabila para tenaga pendidik dan tenaga pelatih memiliki kualifikasi, kompetensi, dan sertifikasi sesuai dengan bidangnya maka akan memudahkan peserta didik dalam mencapai tujuan dari program double track ini.

Selanjutnya, sarana dan prasarana yang digunakan dalam program double track menggunakan fasilitas yang dimiliki SMK. Hal ini lah mengapa yang menjadi salah satu alasan atau syarat sekolah SMA yang diperbolehkan melakukan program ini harus berdekatan dengan SMK, apabila jarak SMA dan SMK berdekatan akan mempercepat mobilitas dalam melakukan pelatihan. Dengan adanya sarana dan prasarana yang mewadahi mempermudah pendidik dan tenaga pelatih dalam memberikan dan menyampaikan materi kepada para peserta didik (Janatusurur, 2019).

\section{4) Sertifikasi}

Berdasarkan Peraturan Pemerintah Nomor 19 Tahun 2005 tentang Standar Nasional Pendidikan (2005) sertifikasi merupakan Alat yang digunakan sebagai wadah penjaminan dan pengendalian dalam mutu pendidikan. Peserta didik yang telah mengikuti kegiatan pelatihan dan sudah memenuhi jam pelatihan yang telah ditentukan, maka berhak untuk mengikuti ujian kompetensi.

Ujian Kompetensi dilaksanakan oleh Sekolah Menengah Atas (SMA) yang menyelenggarakan program double track, ujian kompetensi dilakukan dengan melakukan kerja sama dengan LSP (lembaga sertifikasi). Bagi peserta didik pada SMA penyelenggara double track yang sudah mengikuti ujian dan dinyatakan lulus berhak memperoleh Ijazah Formal dan Sertifikat Kompetensi.

\section{5) Pembiayaan}

Pembiayaan penyelenggara program double track pada SMA dibebankan pada Anggaran Pendapatan dan Belanja Daerah (APBD) Provinsi Jawa Timur pada Dinas Pendidikan. Pembiayaan ini menjadi standar yang mengatur komponen dan besarnya biaya operasi satuan pendidikan (Dinas Pendidikan Jawa Timur, 2018). 
Implementasi Evaluasi Hasil Belajar Pada Sekolah Dengan Program Double Track di Provinsi Jawa Timur

Seperti yang telah diketahui bahwa evaluasi hasil belajar adalah kegiatan untuk mengukur dan menilai kegiatan pembelajaran dari awal hingga akhir, serta untuk menentukan keberhasilan kegiatan pembelajaran. Tak terkecuali program double track yang masih baru pun membutuhkan evaluasi guna mengetahui apakah maksud dan tujuan diadakannya program dapat tercapai. Adapun, bentuk awal penilaian dari hasil belajar program double track ini dimasukkan ke dalam kurikulum muatan lokal karena terdapat beberapa bidang keterampilan yang telah tercangkup dalam mata pelajaran, sehingga nilai dari bidang keterampilan yang diikuti dalam program double track akan tercantum dalam rapor khususnya pada bagian keterampilan. Namun, kini tidak lagi dimasukkan ke dalam muatan lokal tetapi nilai hasil belajar akan dikeluarkan dalam bentuk ijazah formal dan sertifikat.

Sertifikat yang dikeluarkan tentunya berasal dari lembaga profesional utama yang terstandar yaitu ITS (Institut Teknologi Sepuluh November). ITS ini digandeng oleh pemerintah provinsi Jawa Timur tidak hanya sebagai lembaga yang melakukan sertifikasi peserta (siswa) tetapi juga sebagai panitia penyelenggara dan yang akan membimbing para trainer (pembimbing siswa pada masing-masing sekolah). Selain ITS, siswa juga dapat memperoleh sertifikat melalui mitra-mitra yang bekerjasama dengan sekolah. Seperti halnya sekolah dapat bekerja sama dengan E-Bizz untuk bidang TIK,
Airlangga Broadcasting untuk keterampilan pembuatan video, SMET untuk keterampilan bahasa mandarin, dll.

Untuk mendapatkan sertifikat, siswa terlebih dahulu harus melalui evaluasi hasil belajar atau ujian yang dilaksanakan pada akhir semester genap, dari pihak internal sekolah dan bekerja sama dengan mitra sekolah. Evaluasi pada sekolah DT atau double track ini dapat dilakukan dengan 2 cara, yaitu:

\section{1) Uji kompetensi berbasis CBT}

Uji kompetensi ini dilakukan oleh pusat secara serentak di Jawa Timur. Uji kompetensi berbasis CBT dapat dilakukan oleh siswa dengan mengakses aplikasi ujian sertifikasi bernama ruangujian.net secara online. Ujian ini dilakukan untuk mengetahui level kompetensi calon tenaga kerja yang telah mengikuti pelatihan. Sehingga, didalamnya telah disediakan berbagai level ujian yang dapat diikuti untuk mengukur pengetahuan dan keterampilan.

Kelulusan dari siswa ini ditentukan oleh kualitas pengetahuan dan keterampilan yang dievaluasi langsung oleh tim expert melalui aplikasi.

\section{2) Uji praktik}

Uji ini dilakukan dengan tim penilaian pusat datang ke sekolah dan trainer yang memiliki kewajiban untuk menilai. Dalam uji praktik, siswa atau peserta diuji langsung dengan memperlihatkan dari awal proses pembuatan hingga jadi. Setelah produk jadi, siswa akan 
mempertanggung jawabkannya untuk dinilai oleh trainer.

Dari kedua bentuk evaluasi tersebut, nilai yang muncul akan dikalkulasikan untuk didapatkan nilai akhir yang mempengaruhi lulus atau tidaknya siswa dalam program double track. Jika siswa dinyatakan lulus, maka siswa dapat mengikuti private challenge serta mendapatkan points dan sertifikat. Adapun tindak lanjut dari evaluasi hasil belajar ini yaitu siswa yang telah lulus dapat secara mandiri berwirausaha, dalam artian harus menghasilkan produk. Sehingga tidak berhenti ketika mengikuti pelatihan saja.

Tidak hanya sampai pada sertifikasi saja, tetapi juga dilakukan monitoring dan evaluasi terhadap pelaksanaan program double track pada masingmasing sekolah. Monitoring dan evaluasi ini dilakukan langsung oleh tim penilai dengan (1) melakukan kunjungan lapangan untuk melihat pelaksanaan pelatihan di sekolah; (2) melihat ketersediaan alat, bahan, trainer, dan hasil produk pelatihan; serta (3) mendapatkan profil siswa yang sudah mulai bekerja ataupun wiraswasta -kerjasama DUDI (Dunia Usaha dan Dunia Industri).

Adapun output capaian kinerja dari program double track jika dilihat dari aspek jumlah siswa yang terlibat dalam pengembangan produk, jumlah siswa tersertifikasi, dan jumlah produk hasil pelatihan didapatkan hasil sebagai berikut:

\begin{tabular}{|c|c|}
\hline \multicolumn{2}{|c|}{ Calon Tenaga Kerja } \\
\hline Multimedia & 3369 \\
\hline Tata Boga & 4057 \\
\hline Kecantikan & 1808 \\
\hline
\end{tabular}

\begin{tabular}{|c|c|}
\hline Tata Busana & 1537 \\
\hline Elektro & 146 \\
\hline TKRO & 622 \\
\hline
\end{tabular}

Dengan jumlah kemandirian alumni dalam rentang waktu 3 tahun dari tahun 2019-2021 sebanyak:

\begin{tabular}{|l|l|l|l|}
\hline & 2019 & 2020 & 2021 \\
\hline Wirausaha & 172 & 1.340 & 1.916 \\
\hline Bekerja & 516 & 1.381 & 3.832 \\
\hline $\begin{array}{l}\text { Alumni yang sudah } \\
\text { mandiri }\end{array}$ & 688 & 2.721 & 5.748 \\
\hline Total keseluruhan & \multicolumn{3}{|c|}{9.157} \\
& \multicolumn{3}{|c|}{ Siswa Mandiri } \\
\hline
\end{tabular}

Berdasarkan data diatas, maka dapat terlihat bahwa dalam penyelenggaraan double track telah memenuhi visi, misi, dan capaian yang diharapkan. Disertai dengan tata pengelolaan hingga evaluasi hasil belajar yang baik dan teliti hingga berhasil dalam rangka

1) Menyebarkan pusat pelatihan keterampilan yang dapat dimanfaatkan oleh masyarakat.

2) Terciptanya jaringan kerjasama sekolah dengan DUDI.

3) Terciptanya berbagai lapangan pekerjaan, sehingga terjadi penurunan jumlah pengangguran khususnya di provinsi Jawa Timur.

4) Meningkatkan Indeks Pembangunan Manusia IPM Jawa Timur. Pada tahun 2016 IPM Jawa Timur berada di angka 69,74; Tahun 2017 di angka 70,27; Tahun 2018 di angka 70,77; 
Tahun 2019 di angka 71,50; Tahun 2020 di angka 71,71; dan Tahun 2021 di angka 72,14.

5) Menaikkan pendapat perkapita masyarakat Jawa Timur.

\section{Kesimpulan}

Evaluasi hasil belajar sangat dibutuhkan untuk mengetahui dan memahami latar belakang siswa serta menemukan seberapa jauh, berkaitan dengan apa, dan bagian tujuan pendidikan mana yang sudah tercapai. Adapun, bentuk awal penilaian dari hasil belajar program double track dimasukkan ke dalam kurikulum muatan lokal karena terdapat beberapa bidang keterampilan yang telah tercangkup dalam mata pelajaran, sehingga nilai dari bidang keterampilan yang diikuti dalam program double track akan tercantum dalam rapor khususnya pada bagian keterampilan. Namun, kini tidak lagi dimasukkan ke dalam muatan lokal tetapi nilai hasil belajar akan dikeluarkan dalam bentuk ijazah formal dan sertifikat. Tidak hanya sampai pada sertifikasi saja, tetapi juga dilakukan monitoring dan evaluasi terhadap pelaksanaan program double track pada masing-masing sekolah. Penyelenggaraan double track telah memenuhi visi, misi, dan capaian yang diharapkan. Disertai dengan tata pengelolaan hingga evaluasi hasil belajar yang baik dan teliti.

\section{Daftar Pustaka}

Anas Sudijono. (2012). Pengantar Evaluasi Pendidikan. Jakarta: PT. Raja Grafindo Persada

Arifin, Zainal. (2013). Evaluasi Pembelajaran. Bandung: PT Remaja Rosdakarya.
Arikunto, Suharsimi. (2009). Dasar-dasar Evaluasi Pendidikan. Jakarta:Bumi Aksara

Badan Pusat Statistik Provinsi Jawa Timur. Data Indeks Pembangunan Manusia 2016-2018 dan Data Indeks Pembangunan Manusia 2019-2021. [Internet]. Tersedia pada: https://jatim.bps.go.id/indicator/26/36/1/ipm/html [Diakses pada 14 Desember 2021]

Baskoro, F. (2019). Monitoring Evaluasi Program Double Track. [Internet]. Tersedia pada: https://www.slideshare.net/fajarbaskoro/monitorin g-evaluasi-program-double-track-201234582

[Diakses pada 12 Desember 2021]

Baskoro, F. (2019). Program SMA Double Track. [Internet]. Tersedia pada: https://www.slideshare.net/fajarbaskoro/programsma-doubletrack [Diakses pada 12 Desember 2021]

Berita Resmi Statistik No. 84/11/th. XXIV, 05 November 2021

Dinas Pendidikan Jawa Timur. (2018). Program SMA / MA Double Track.

E. Mulyasa, Implementasi Kurikulum Tingkat Satuan Pendidikan, Jakarta, Bumi Aksara, 2013, Hal. 56

Iriani, Dwi Sapitri dan Soeharto. (2015). Evaluasi Pelaksanaan Praktik Kerja Industri Siswa Kompetensi Keahlian Jasa Boga SMK N 3 Purworejo. Jurnal Pendidikan Teknologi dan Kejuruan (Volume 22 Nomor 3). Hlm 275-290

Janatusurur, R. (2019). Pengaruh Sarana dan Prasarana Belajar Terhadap Hasil Belajar Siswa (Studi Kasus Pada Mata Pelajaran Ekonomi di Kelas XII IIS SMA PGRI Bandung). 11-38. Tersedia pada: https://doi.org/10.31227/osf.io/umk2t [Diakses pada 12 Desember 2021]

Kholis, N. (2021). Implementasi Program Double Track Sebagai Upaya Peningkatan Keterampilan Ekonomi Kreatif Di SMA NU 1 Gresik. Surabaya: UIN Sunan Ampel

Maula, D. A. (2021). Implementasi Kebijakan Program Double Track Di SMA Negeri 1 Tongas Kabupaten Probolinggo. Malang: Universitas Muhammadiyah Malang

Nurdin Usman, (2002) Konteks Implementasi Berbasis Kurikulum, Grasindo, Jakarta, Hal. 70.

Peraturan Gubernur Jawa Timur Nomor 139 tahun 2018 tentang Program Double Track pada Sekolah Menengah Atas di Jawa Timur. (2018). Director, 15(40), 6-13. Retrieved from http://awsassets.wwfnz.panda.org/downloads/eart h_summit_2012_v3.pdf\%0Ahttp://hdl.handle.net/ 10239/131\%0Ahttps://www.uam.es/gruposinv/me va/publicacionesjesus/capitulos_espanyol_jesus/2 $\underline{005}$ 
Pers Smandasa. (2020). Monitoring dan Evaluasi Program SMA Double Track di SMAN 1 Dander. [Internet]. Tersedia pada: https://sman1dander.info/2020/01/10/monitoringdan-evaluasi-program-sma-double-track-di-sman1-dander-2/ [Diakses pada 12 Desember 2021]

Purwanto dan Sulistyastuti, (1991) Analisis Kebijakan dari Formulasi ke Implementasi Kebijakan, Bumi Aksara Jakarta, Hal. 21

Setiawan, Guntur. (2019). Implementasi dalam Birokrasi Pembangunan, Balai Pustaka, Jakarta, Hal. 39

SMA Double Track. (2021). Akselerasi Cipta Kerja Melalui Kelompok Usaha Siswa DT. Dinas Pendidikan Provinsi Jawa Timur dan Institut Teknologi Sepuluh November

Sukardi. (2013). Metodologi Penelitian Pendidikan Kompetensi dan Praktiknya. Jakarta: PT Bumi Aksara.

Undang-Undang Sistem Pendidikan Nasional No. 20 tahun 2003 Tentang Sistem Pendidikan Nasional 